\title{
The theory and method of comparative area studies
}

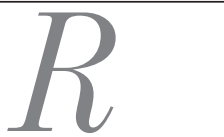

Qualitative Research Copyright (C) 2011 The Author(s) http://qrj.sagepub.com vol. 11(1) 69-90

\author{
ARIEL I. AHRAM \\ Department of Political Science, University of Oklahoma, USA
}

ABSTRACT Though many now downplay the tension between area studies and disciplinary political science, there has been little substantive guidance on how to accomplish complementarity between their respective approaches. This article seeks to develop the idea of comparative area studies (CAS) as a rubric that maintains the importance of regional knowledge while contributing to general theory building using inductive intra-regional, cross-regional, inter-regional comparison. Treating regions as theoretically-grounded analytical categories, rather than inert or innate geographical entities, can help inform both quantitative and qualitative attempts to build general theory.

KEYWORDS: analytic narratives, area studies, qualitative methods, quantitative methods, rational choice

\section{Introduction}

In recent decades there have been several attempts to declare a truce between area studies and disciplinary political science, focusing on potentials for complementarity instead of competition (Bates, 1997; Hanson, 2008; Katzenstein, 2001). ${ }^{1}$ Little substantive guidance, however, has been offered about how to accomplish this conciliation. While the truce appears to be holding within comparative politics as a sub-field, the most prestigious general interest political science journals overwhelmingly publish large-n quantitative analysis or deductive models at the expense of country or region-specific studies (Bennett et al., 2003; Mahoney, 2007; Munck and Snyder, 2007a). The upper-echelons of the discipline appear relentless in adopting Przeworski and Teune's (1970: 30) prescription that social scientists seek to replace proper names with relevant variables, either through large-n, quantitative analysis or qualitative analytical narratives that emphasize abstract and universal mechanism. ${ }^{2}$ In return, area studies experts often scoff at efforts to categorize and group (in political science parlance, 
'to code') countries on scales made to measure the entire world and point out the poverty of the generic theories that seem to explain everything and yet nothing in particular (Johnson, 1997; Williams, 2000). If, as Acharya (2008) and Katzenstein (2005) contend, regions are central to our understanding of world politics, then efforts to displace them are sorely misplaced.

This article argues that insights from area studies cannot be ignored by those aspiring to general theory, but at the same time, area studies itself must adopt a new approach to qualitative and mixed methods in order to assert its role in general theory development. The article proceeds in four sections. The first section explains what area studies specialists mean when they talk about regions. Rather than geographic givens, regions are analytic categories grounded in historical processes that cluster spatial, temporal, and institutional contexts between and above the country-level unit. The second section examines the ways quantitative analysis approaches regions and demonstrates that although statistical methodologists using large-n, cross-national regression claim to have surpassed the need for area studies, their work fails to capture or explain important aspects of regional variation. The third section contrasts the shortcomings of quantitative analysis with the traditional affinity for qualitative methods in area studies. With rational choice theory's ascendance, however, area studies faces both challenges and opportunities to engage in more dynamic comparisons. The last section integrates these arguments with Basedau and Köllner's (2007) recent suggestion of moving toward a truly comparative area studies (CAS) by adding inter-regional and crossregional comparison to the traditional repertoire of single, intra-regional studies. Placing qualitative methods at the analytical fulcrum, CAS has the potential to maintain the integrity of regional knowledge while better relating the insights of area studies to the wider discipline of social science.

\section{What is a region?}

Both positivist and post-positivist strands within political science have found reason to criticize the practice of area studies. Ironically, both have been correct in their assessments in their own ways. On one hand, the insistence of limiting inquiry to small cluster of geographically proximate countries has tended to foster artificial geographic barriers to general social theory. At the extreme, area studies' focus can be so narrow as to make particular countries or places appear sui generic and immune to comparison with any other places or peoples. On the other hand, one need not move too far down the poststructuralist road to recognize that the current delineation of five (occasionally six) world regions and the erection of area studies centers in American universities was a construct closely intertwined with the projection of American power during the cold war. Area studies as such reflect more a particular imperial perspective than a useful analytic device (Lewis and Wigen, 1997). 
In both indictments, regions appear as arbitrary groupings lacking clear conceptual coherence. Latin America spans from the Antarctic Circle to the tropics. Although Spanish is the predominant language and Catholicism the dominant religion, there are also significant pockets where other European and indigenous languages predominate, as do practitioners of other religions. This, however, is a far more consistent and coherent grouping than that delineating Southeast Asia, whose member countries appear only to have Japanese occupation during World War II in common (Mirsepassi et al., 2003; Miyoshi and Harootnunian, 2002; Szanton, 2004). The nebulous nature of regional domains is reflected in the fact that alternative scheme of regional classification are constantly being offered. Huntington (1996), for example, provocatively claims that broad affinities between 'civilizational' blocs subsume individual countries and define the trajectories of social change and international conflict. More innocuously, Lewis (2002) divides the world by the culinary utensils, distinguishing the fork, finger, and chop-stick zones.

What area studies tends to lack is a conceptual - instead of taxonomical defense of regions as analytical categories. To this end, Hanson offers a theoretical justification for area classification and a model of regional differentiation. Nearly all accounts of individual regions share a common historical pathway: They begin with a period of imperial expansion or retreat, embedding a territory with common linguistic, religious, political, or economic institutional modes. Once imprinted by these molds, countries and societies within this territory tend to influence each other through diffusion, emulation, and competition (Hanson, 2008: 38-9). In other words, regional differentiation is a process involving the 'deep impact' of a critical junctures followed by interactions that perpetuate and deepen the cleavages between regional clusters (Capoccia and Kelemen, 2007; Goldstone, 1998; Pierson, 2004).

In this regard, Rokkan's 'conceptual map' of Europe, based on the 'mastervariables' of religion, language grouping, urbanization, and landholding structures, is paradigmatic. Europe is neither an innate nor inert grouping of countries, but a space buffeted by continual processes of cultural, political, and economic integration and differentiation, beginning with the advent of the Roman empire and continuing through the formation of various medieval kingdoms and their feudal vassals. These simultaneously helped bind Europe's emergent states together, but also cross-hatched them with different institutional endowments and launched them on different long-term courses. While different master variables may be applicable in other global settings, Rokkan's efforts offer a model by which to appreciate the complex factors involved in regional definition, setting certain countries apart from their neighbors into larger clusters. ${ }^{3}$

The ultimate decision about regional classification schema depends on logical conjecture about which types of critical juncture and which forms of interactions matter most to a given social scientific puzzle. While regions tend to be 
premised on spatial proximity, they could be construed on any number of other theoretical criteria, such as common settings in world historical timing ('the post-Communist world'), economic attainment ('advanced industrial democracies'), or culture ('the Islamic world'). Each of these analytical categories implicitly relies on assumptions about common features uniting the countries in these regions and recognizes that in having these features in common, interaction between countries in these clusters is more common (Fawcett, 2004; Thompson, 1973).

No schema is totalizing or exclusive. Sudan, for instance, sits across and within multiple, hierarchically-arranged regions, simultaneously part of the Middle East, Africa, the Muslim World, and the economic periphery, among others. Moreover, schemas are based fundamentally on an inductive, fuzzy-set relationship (Ragin, 2000). Early versions of dependency theory, for instance, held that the timing of integration into the global market accounted for the modes of economic production. The distinction between economic 'core' and 'periphery' regions is a mixed metaphor aimed to capture simultaneously temporal, spatial, and institutional variation. As dependency theory matured, however, these two regional categories proved insufficient to capture the evident diversity of economic systems, so a new region ('semi-periphery') was later introduced (Bratton, 1982).

The more conceptual specificity used in the grouping of countries into regions, the more analytical leverage these categories provide in understanding social change and, in turn, the building of general theoretical knowledge. As with all analytical tools, then, it is incumbent on the individual practitioner to provide explicit theoretical justification and to recognize the unique strengths and weakness for whatever the regional categorization schema is adopted. The following sections demonstrate that this logic has largely eluded most quantitative studies and is even in peril in qualitative methods dominated by rational choice.

\section{Regional diversity and cross-national quantitative analysis}

Since at least the 1960s and the behavioral revolution, large-n, cross-national statistical studies have been the nemesis of area studies, challenging its insistence on close focused observation of a small number of cases. It is not that large-n analyses deny the possibility that regional units have distinct social qualities. As Brinks and Coppedge, for instance, caution in their quantitative study of patterns of democratization, any model that does not account for spatial relations among neighboring countries is theoretically underspecified (Brinks and Coppedge, 2006: 484-5). This echoes the sentiment of geographers, who had earlier noted the specifically regional patterns of democratic transitions (O'Laughlin et al., 1998). Datasets which quantitative researchers tend to rely on for country-year data, like POLITY or World Development 
Indicators, even provide a column for Africa, Middle East, Latin America, etc. (Ebbinghaus, 2005; Kittel, 2006). ${ }^{4}$ But most large-n cross national studies follow the example of studies in voting behavior and proceed with the confidence that all manifestations of regional divergence can eventually be explained by a properly specified conceptual variable (Gieryn, 2000: 476; King, 1996).

Spatial, temporal, institutional, or cultural clustering above the basic level, however, violates fundamental statistical assumption about unit homogeneity and independence (Luke, 2004: 8, 20-3). Quantitative research relies upon multilevel models to relax assumptions about unit independence and capture supra-unit interaction. One or more dichotomous regional dummy variables are added to the table, indicating whether a country does or does not belong to a certain regional grouping. These dummy variables can then be multiplied by (interacted with) other conceptual variables to create a random effects model that identifies variation both at the regional and the country-level unit (Di Prete and Forristal, 1994: Franzese, 2005; Geller and Hill, 2007; Western, 1998).

Consider this simple example of a study examining the correlation between per capita GDP and rates of malnutrition. ${ }^{5}$ The country-level analysis is depicted in Equation 1 below

\section{Equation 1}

where

$\mathrm{Y} \quad=\%$ of population malnourished

GDP = log natural of per capita wealth in constant 2000 US dollars

The overall fit appears strong and the residuals fairly evenly distributed. Still, an examination of spatial representation would show that countries of Middle East and North Africa states (marked by squares) have far lower malnourishment than comparable units. Adding a dummy variable for major Middle Eastern and North Africa (MENA) in Equation 2, we can calculate a parallel regression for MENA versus the rest of the world, depicted in Graph 1.

\section{Equation 2}

where

$\mathrm{Y} \quad=\%$ of population malnourished

GDP = log natural of per capita wealth in constant 2000 US dollars

MENA $=1$ for Middle East/North Africa countries

$=0$ for non-MENA

So far, this analysis has shown that certain geographically proximate states are regularly aberrant from the global developmental pattern. The dummy variable seems to adequately control for this aberration. Yet the dummy variable 
is just a mechanical mathematical devise; it does not explain the ways in which a particular regional cluster differs from all others. To interrogate this question further, a multilevel model with interaction terms must be used, further relaxing the assumption of unit independence. Equation 3 shows the interaction terms for constructing such a multilevel model using the same example above.

\section{Equation 3}

where

$$
\mathrm{Y}=\alpha+\beta_{1} \mathrm{GDP}+\beta_{2} \mathrm{MENA}+\beta_{3}(\mathrm{MENA} * \mathrm{GDP})+\mathrm{u}
$$

$\mathrm{Y} \quad=\%$ of population malnourished

GDP = log natural of per capita wealth in constant 2000 U.S. dollars

MENA $=1$ for Middle East/North Africa countries

$=0$ for non-MENA

In Graph 2, the flattened slope of the MENA line indicates not only that MENA states on average have less malnutrition than other developing states, but that food security in MENA is much less dependent on increases in overall wealth. Thus, the interaction of overall wealth and food distribution is conditioned by region level variables, a fact which would be statistically imperceptible without using a multilevel, interactive analysis.

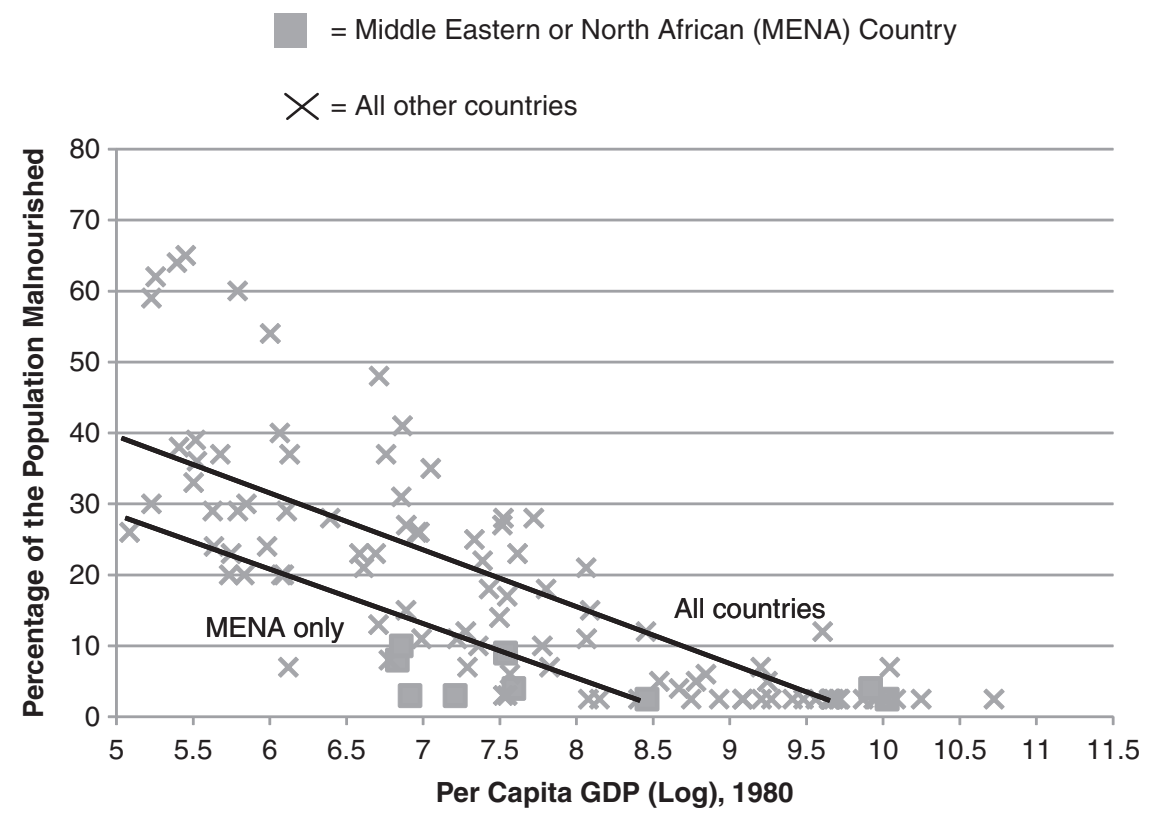

GraPh 1. Malnutrition and Per Capita GDP, 1980 (Dummy Variable Only) Source: World Bank World Development Indicators 


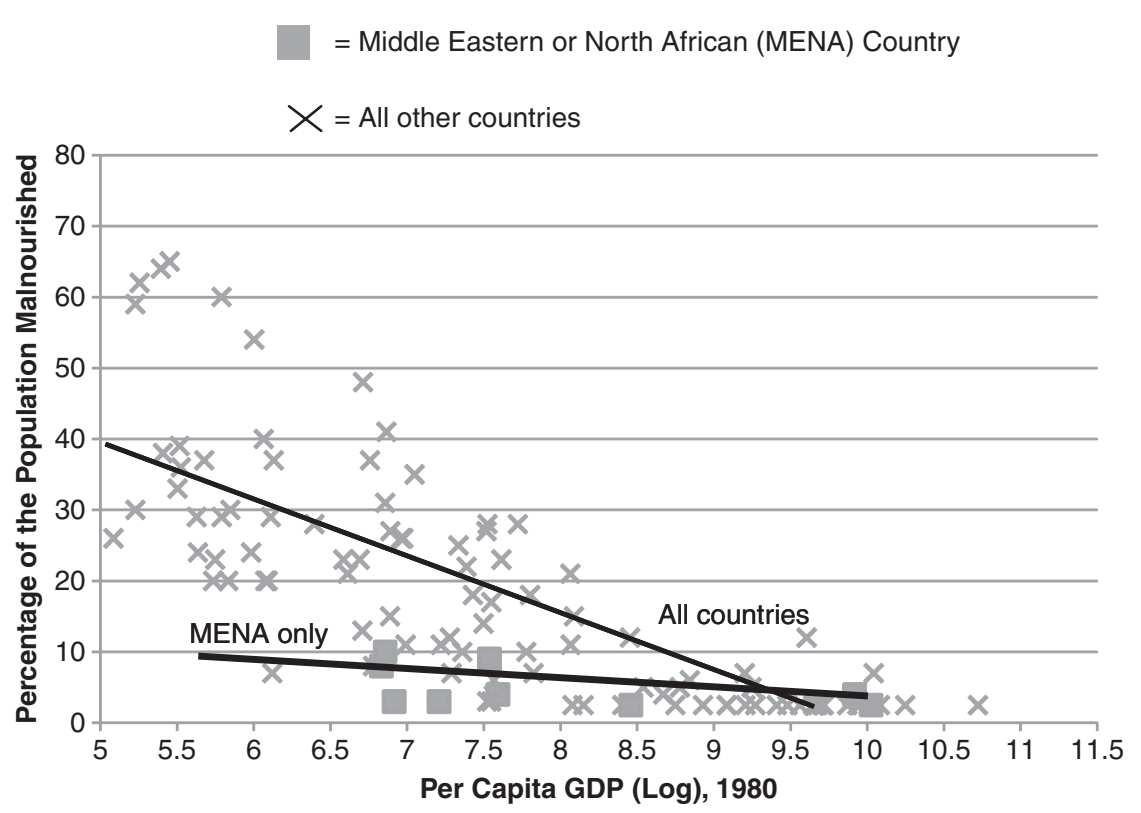

Graph 2. Malnutrition and Per Capita GDP, 1980 (Interaction term included) Source: World Bank World Development Indicators

But even though multilevel models are available to quantitative researchers in theory, they are difficult to employ and impose a steep statistical penalty in practice (Ragin, 2008: 112-4; Shalev, 2007: 243). A three year survey of articles from seven major journals demonstrates how rarely they are actually used to capture regional variation. The sample consists of the three leading general journals in political science and three leading comparative politics journals which Mahoney (2007) and Munck and Snyder (2007b) respectively identify in their surveys of the discipline. It also contains one journal (Journal of Conflict Resolution) that specializes specifically in quantitative methodology. As shown in Table 1 below, 82 articles in the sample employed large-n cross-regional regression, logit/probit, or hazard models. Of these, only 22 used fixed effects models to test for regional heterogeneity and only two used multilevel models.

It is not just that techniques to analyze regional differentiation are underutilized, however. When regions do appear as independent variable, researchers rarely discuss the specific content of the regional cluster to which they ascribe causal significant or consider alternative schema of regional classification that might yield different results. There is little theoretical justification for including these variables beyond the rote attempt to soak up unexplained variance (Engelbert, 2000; Lieberman, 2005: 438).

Atheoretical treatment of regional dummies leads ineluctably to 'garbage can' statistical models (Achen, 2002; Luke, 2004: 23; Steenbergen and Jones, 
TABLe 1. Use of Regional Dummy and Interaction Terms in Cross-Regional Regressions, 2003-2005

\begin{tabular}{|c|c|c|c|c|}
\hline Journal Name & $\begin{array}{c}\text { Total } \\
\text { Number of } \\
\text { Articles }\end{array}$ & $\begin{array}{l}\text { Articles } \\
\text { Using Cross } \\
\text { Regional } \\
\text { Regressions }\end{array}$ & $\begin{array}{c}\text { Articles Using } \\
\text { Regional } \\
\text { Dummy } \\
\text { Variables }\end{array}$ & $\begin{array}{c}\text { Articles Using } \\
\text { Regional } \\
\text { Interaction } \\
\text { Terms }\end{array}$ \\
\hline $\begin{array}{l}\text { Journal of Conflict } \\
\text { Resolution }\end{array}$ & 115 & 32 & 8 & 0 \\
\hline $\begin{array}{l}\text { American Political } \\
\text { Science Review }\end{array}$ & 88 & 9 & 2 & 1 \\
\hline $\begin{array}{l}\text { American Journal of } \\
\text { Political Science }\end{array}$ & 154 & 17 & 4 & 0 \\
\hline Journal of Politics & 163 & 5 & 0 & 0 \\
\hline $\begin{array}{l}\text { Comparative Political } \\
\text { Studies }\end{array}$ & 121 & 13 & 6 & 1 \\
\hline Comparative Politics & 52 & 2 & 0 & 0 \\
\hline World Politics & 48 & 4 & 2 & 0 \\
\hline TOTAL & 741 & 82 & 22 & 2 \\
\hline
\end{tabular}

2002: 234). Several specific problems are evident: Some studies are inconsistent in the use of regional dummies and thus miss important opportunities for accumulation of knowledge about a particularly puzzle. For instances, in a study of trade reform and liberalization among middle-income states with presidential electoral systems, Nielson (2003) divides his dataset into Latin American and non-Latin American states, while Samuels (2004) examines a similar puzzle and population but without including such a dummy. A closely related problem is the non-comprehensive use of regional dummies, as when a study inexplicably controls for only one regional dummy (often the nuisance region of Sub-Saharan Africa) and leaves the rest of the (normal) world as benchmark (Cf., Humphrey, 2005; Smith, 2004; Timmons, 2005).

Another derivation of this problem is including dummy variables but then neglecting to report or interrogate their coefficients and significance (Cf., Mukherjee, 2003; Pinto and Timmons, 2005). Ferrera and Herron (2005) propose the null-hypothesis of no difference in party institutionalization between post-Communist and more established democracies, but when the dummy variable specifically shows significant regional variation, they provided no discussion of it. In a study of the effects of globalization on terrorism, $\mathrm{Li}$ and Schaub beg the question by noting the necessity of including regional dummy variables for Europe, MENA, Sub-Saharan Africa, Asia, and North and South America because 'terrorist incidents are unevenly distributed geographically' (Li and Schaub, 2004: 243). Similarly, Birch explains away the significance of the regional dummies in a study of the effect of different electoral systems on democracy by concluding that the " $[\mathrm{t}]$ he poor democratic credentials of many states in [the Middle East and North Africa, Sub-Saharan Africa, 
and Asia] appear to be related to cultural, physical, or other attributes of states not included in these models and do not seem to be a function of institutional design or colonial legacy' (Birch, 2003: 334). Thus, most of the world's population is apparently exceptional to his model.

This survey of the existent literature demonstrates a significant lag between theory and practice of large-n analysis in regards to understanding regional divergence. Prevalent techniques of cross-national statistical analysis essentially slip in through the backdoor the proper nouns that were not allowed in the front door of stringently general social science. If they even bother to test for regional variation, large-n studies remain at a loss to explain it. Large-n analysis overlooks the immense diversity in macro-social outcomes, leaving general theories that are often little more than platitudes meant to describe every case in every condition.

\section{Qualitative methods, area studies, and the hegemony of rational choice}

Unlike quantitative methods, the relationship between area studies and qualitative methods has traditionally been more amicable. Most area studies, after all, employs focused comparison, quasi-Boolean logic, and narrative process tracing to gain leverage on elements of causal complexity in a relatively small universe of cases (Abbott, 2001; George and Bennett, 2005; Gerring, 2007). For instance, regarding the example of the low rates of malnutrition even in poor MENA states, area studies specialists have long pointed out a particularly durable form of 'authoritarian bargain' that emerged under the colonial and immediate post-colonial period. Governments throughout the region undertook massive efforts to ensure adequate food supply and provide a strong social safety net to peasants and workers in return for political quietude (Heydemann, 2007; Yousef, 2004). These types of insights into historical emergence of large scale- macro-social outcomes are exactly the traditional strength of area studies.

With the rise of rational choice and its emphasis on identifying discrete sets of universal mechanisms to explain human behavior, though, area studies has confronted both new challenges and new opportunities within the qualitative realm. Especially in its early articulations, rational choice was imperious in its claims to universal models of human behavior based on the deductive game theoretic formulae. It was only with the adoption of the analytic narrative technique that rational choice staked its theoretical sophistication against empirical evidence, attempting to reconstruct mechanisms of individual rational calculations that led to observable aggregate social outcomes. There are both complementary and competitive elements in relationship between rational choice and area studies. On one hand, rational choice (at least in its analytic narrative form) gave explicit warrant 
to pursuing data across the globe, even in regions that were considerable marginal to the mainstream of comparative politics. Bates, whose work on the political economy of Africa had long utilized a rational-actor perspective, was one of the first proponents of analytic narrative. Regional experts were invited to search for, observe, and report on universal processes in far-off places in order to test propositions and find new data. On the other hand, rational choice assailed area studies' parochial and ideographic tendencies as barriers to generalizations, the ultimate goal of 'true' science.

The friction between rational choice and area studies relates to the question of what should be the focus of a narrative. For rational choice, it is the mechanisms that are the main characters (Bennett and George, 2001: 147-52). Mechanisms are unobservable, recurrent, abstract micro-level processes that connect macro-level initial conditions and macro-level outcome (Elster, 1991: 23-4; Gerring 2008). As its name implies, rational choice's menu of mechanisms is relatively short, focused on the deliberate actions of utility-maximizing agents. Even with the inclusion of the possibility of misjudgment, incomplete information, and subjective preference-ranking, rational choice is aggressive in its methodological individualism. The aggregate of acts by such purposeful (though not omniscient or infallible) agents generates macro-political outcomes (Hedström and Swedberg, 1996; Monroe, 2001).

Rational choice has faced serious methodological and epistemological criticism (Shapiro, 2005), but the main argument from area studies is not that rational choice's assumption of self-interested individual are necessarily wrong. ${ }^{6}$ Rather, the main area studies critique of rational choice is that by 'cut[ting] deeply into the specifics of time and place' to get to the 'essence' of stories, (Bates et al., 1998: 12), rational choice tends to amputate the contextual features that bound political behavior, underplaying the most important and interesting features of social change. There is a certain aesthetic element to this criticism. Analytic narratives often read like repetitions of the same script of a two- (or sometimes four-) player one act shows, reciting again and again the lines of the prisoner's dilemma or the battle of the sexes. The more parsimonious and universal mechanisms become, the most likely they are to seem banal (Roberts, 1996: 66-7). Analytic narratives tend to miss or dismiss elements of suspense and uncertainty in outcomes, contingency inherent in games with multiple equilibria, and conjectures that involve concatenation of many events, agents, and sequences (Carpenter, 2000).

Area studies, in contrast, places in the foreground the contextual variation which rational choice shuns to the background. Context is the foil with which mechanisms collide, the specific analytical, temporal, spatial, or institutional configurations that constrain processes of social change (Bunge, 1997; Falletti and Lynch, 2006). As Geertz famously quipped, a purposeful wink of the eye and unconscious tick can only be distinguished by knowledge of the setting in which the act occurs (Geertz, 2000: 6-7). States Mayntz, 'it is not possible to 
build a substantial theory out of context-free, general mechanisms' (Mayntz, 2004: 254). Explanations about concrete macro-social phenomena, like the distribution of property, the erection of different of economic institutions, the adoption of religion, or the enactment of mass protests, require situating mechanism in the midst of specific social and historical moments (Kittel, 2006: 667).

Among the most dire problems rational choice faces is its inability to taking into account the symbolic systems which impute particularly identities and preference sets to individual agents (Blyth, 2003; Hechter and Kanazawa, 1997: 209). Take, for example, Laitin's study of language acquisition and ethnic identity in post-Soviet space. Laitin argues that Russians living in the Near Abroad choose to adopt the language of the titular national state when they believe it is in their interest to do so, but that the perception of benefit hinges on the anticipated moves that others make. The aggregate result is a cascading dynamic in which all Russians adopt the national language or none. But as Laitin himself notes, Russians tend to be especially resistant to learning Ukrainian or Turkic languages. The former is denigrated as a bowdlerized Russian dialect, the latter deemed barbaric. In contrast, learning a Baltic language is more acceptable because it is considered a 'Western' language (Laitin, 1998: 117-21, 155-61). Thus, while stressing the universality of his tipping model, the plasticity of linguistic identity, and instrumentality of individuals, the outcomes Laitin actually identifies are deeply constrained by the exogenous and ideographic legacies of Russian imperialism and Great Russian chauvinism.

An area studies approach would not necessarily deny the importance of these ubiquitous acts of rational calculation, but re-center the narrative to emphasize those contextual elements that make the outcome in question unique. Area studies narratives have a more intricately-rendered setting, more expansive cast of characters, and unfold under a longer durée than typical analytic narratives. Consider the differences between the accounts of Africa state frailty and failure by Bates (2008) and Herbst (2000). They are in basic agreement about the logic of Africa's state leaders pursuing short-term policies for immediate gain that which ultimately harm long-term prospects for economic growth and political stability. But for Bates, Africa merely provides a 'fable' in which two agents - the state and the citizen - interact in attempt to achieve public order in which citizens can engage in economic development while the state provides protection in return for extracting taxes. The specific factors that influence state calculations about whether to protect or prey on citizens are only vaguely mentioned and illustrated in a few summaries of the history of individual African states. To test his theory, Bates offers a logistical regression across a country-year panel of African states from 1970 to 1995. What Bates ultimately proves is that Africa's leaders are yet another example of Olson's hypothetical bandits, teetering between the decision to rove or remain stationary (Olson, 1993). 
Herbst's account, in contrast, provides more detail on antecedent conditions, examines a longer length of the causal chain, and offers more prescriptive richness. Herbst traces the lineage of Africa's weak states to specific aspects of precolonial and colonial history. Territorial borders, physical infrastructure, systems of land-tenure, and organization of national bureaucracies and armies were all bequeathed to independent African states by colonial rule. Colonial powers often purposefully fragmented coercive authority, resting it in the hands of tribal and ethnic leaders instead of the state. He specifically shows how these colonial legacies continue to bind the decisions state leaders make today and have a determining impact on state's facility for penetrating society and regulating markets. Since so many African states were born with low infrastructural power, they have an immediate and logical predisposition toward predation. Herbst also depicts the maintenance of public order as a more than simply a two-player contest between state and domestic society. Where Bates merely mentions of the impact of international community and global markets, Herbst highlights the crucial role of superpowers in rewarding existing states and penalizing attempts to establish new state structures, essentially foreclosing the option to re-design states either through war or secession. On the question of why African states veer toward predation more than European, the answer is not the differences in decision-making processes, but in a very specific structure of incentives (Herbst, 2000: 26, 130).

All of this can be summarized as saying that the 'area' in area studies still matters. Even if two voters enact a common mechanism when inside the ballot box, the content and ramifications of their actions depend enormously on whether a vote is cast in Berlin or Bougainville. As rational choice theory has engaged with more diverse empirical cases, it has adopted a more 'institutionalist' perspective that brings it closer to the historically-oriented tradition of area studies (Katznelson and Weingast, 2005; Peters, 2005: 10). But even as rational choice seeks to engage in theoretical history, area studies reiterates that the drift away from actual history and context yields a product that is dull and un-insightful (Soltan, 2004). As Solow warns, data are expensive and theory cheap (Solow, 1997: 56-7). As discrete menus of abstract mechanisms are enumerated, structure and context assume even more relevance within qualitative analysis precisely because they are manifestly diverse and concrete. These elements are crucial to explaining the specific choices rational actors make and the macro-social outcomes that ensue. The section below goes further in discussion of new techniques that can help bring the insights of area studies to bear in larger theory building.

Ultimately, the relationship between area studies and the larger discipline of political science depends on what Emmerson (2008) calls the 'terms of enlistment.' Some consign area specialists to collectors of the 'raw' observations and data which can then be interrogated (at a safe distance) using the discipline's powerful analytical tools. Others place them in the position of devil's advocate, 
providing reality-checks on formal models and statistical analysis. Area specialists continue to assert their centrality in both theory-building and theorytesting and list a pantheon of regional specialists who have made significant contributions to theories of political development, nationalism, and democratization, among others important puzzles. ${ }^{7}$ Still, for area studies to make its insights more substantive and arguments more forceful, it must establish methodological foundations that link both quantitative methods and the rational-choice, qualitative paradigm.

\section{Toward comparative area studies}

Basedau and Köllner (2007) suggest of a new rubric of comparative area studies (CAS), which explicitly addressed the 'terms of enlistment' by which area studies engage with the discipline of political science and expands its methodological repertoire. As shown in Table 2, below, CAS includes the traditional mainstay of area studies, what Bunce (2000) dubs 'bounded generalizations' within a single region.

Typically qualitative in form, bounded generalizations render regional context as scope conditions limiting the enactment of mechanism. For example, Mainwaring and Perez-Liñán $(2003,2004)$ argue that diffusion is an important mechanism sustaining democracy in Latin America despite lower levels of economic development. They explain this region-level variation by pointing to the dissemination of new norms among the elites and masses, made possible by the predominance of the Spanish vernacular, anti-authoritarian stance of the Catholic Church, and new aggressive policies by the Organization of American States in refusing to accept authoritarian retrenchment. Similarly, in the former Communist zones of Eurasia, Bunce and Wolchik (2006) and Beissinger (2007) identify the commonalities

TABLE 2. Three Types of Comparative Area Studies (CAS)

\begin{tabular}{|c|c|c|c|}
\hline & $\begin{array}{l}\text { Intra-regional } \\
\text { comparison } \\
\text { ('Bounded } \\
\text { Generalization') }\end{array}$ & $\begin{array}{l}\text { Inter-regional } \\
\text { comparison }\end{array}$ & $\begin{array}{l}\text { Cross-regional } \\
\text { comparison }\end{array}$ \\
\hline $\begin{array}{l}\text { Object of } \\
\text { comparison }\end{array}$ & $\begin{array}{l}\text { Comparing entities } \\
\text { within geographic } \\
\text { areas }\end{array}$ & $\begin{array}{l}\text { Comparing different } \\
\text { geographic areas as } \\
\text { analytical units }\end{array}$ & $\begin{array}{l}\text { Comparing entities } \\
\text { from different } \\
\text { geographic areas }\end{array}$ \\
\hline Examples & $\begin{array}{l}\text { Political parties in } \\
\text { Southern Africa }\end{array}$ & $\begin{array}{l}\text { Regional co-operation } \\
\text { in Southeast Asia } \\
\text { versus Latin America }\end{array}$ & $\begin{array}{l}\text { Resource-rich } \\
\text { countries in } \\
\text { Africa, Latin } \\
\text { America, and the } \\
\text { Middle East }\end{array}$ \\
\hline
\end{tabular}


of experience and the perception of a shared fate held by pro-democracy opposition as factors leading to the diffusion and emulation of effective tactics for challenging unfair electoral practices. Bounded generalizations use intra-regional variation to validate theories, focusing on variation among clusters of fairly similar cases (Basedau and Köllner, 2007: 7, 15-6; Ekiert and Hanson, 2003).

The techniques of CAS, however, insist that considerable leverage can be gained by returning to the theoretical underpinning of regional differentiation what specifically binds a bounded generalization? The answer seems obvious to the area specialist, but is far from trite from the perspective of the discipline. Explicit emphasis on contextual boundaries generates important observable implications that can further hone theoretical arguments. For instance, if language and religion are important media for the diffusion of democracy in Latin American, a crucial test for this theory would come from those portions of Latin America that did not fall under Spanish domination or are not predominantly Catholic.

Amorphous contextual boundaries lead to overly ambitious or artificially circumscribed generalizations (Goertz and Mahoney, 2006). On one hand, Mozaffar et al. (2003) overreach in their desire to generate general theory about ethnicity and democracy. Since all of their data are derived from Africa, their analysis frequently points out unique features of African society and history that impinge on mechanisms and significant portions of their conclusions pertain solely to Africa. On the other hand, Bratton and van de Walle (1994) narrow the scope of their arguments by creating typologies of 'African' political regimes unrelated to any data or conceptual input from Latin America or East Asian variants. A single region may be a good place both to test and build theories, but such case selection must be considered ad hoc unless accompanied by a justification for the application of scope conditions.

CAS also pushes area studies beyond bounded generalizations toward interand cross-regional comparisons. Could the diffusion of democracy have occurred in the absence of a common linguistic and religious heritage, as is the case in Southeast Asia? Could the Arab world - itself a product of similar expansion of linguistic and religious communities - witness a similar pattern of diffusion? These kinds of questions invite researchers to traverse intraregional contextual homogeneity and identify cases of comparative analytical, instead of geographic, proximity (Locke and Thelen, 1995; Pierson, 2003). Scott's (2009) tracing the impact of imperial conquest and disintegration in shaping the cultural, political, and economic geography of Southeast Asia is exemplary because it explains coherent patterns in the region's formation while highlighting important aspects of intra-regional heterogeneity which are used as fodder for comparison with other regions. Again, the greater the conceptual specificity underlying regional classification schemas, the more it contributes to such efforts at cross-regional comparisons. 
Often the sheer span of history and geographic knowledge involved in such 'contextualized comparisons' requires the collaboration of numerous authors. For example, Beissinger and Young (2002) bring together specialists in Africa and the Soviet Union in an edited volume devoted to understanding the diverse paths leading to breakdowns of internal order and state control. They note how in Africa 'state crisis emerged in the wake of independence rather than as a precipitant of [national] independence' while in post-Soviet Eurasia 'the collapse of the traditional social controls exercised by the Soviet state preceded and indeed very much precipitated independence' (p. 37). Recognizing that state crisis is a common feature of both regions, the book takes great pains to show how both similarities and differences in outcomes were conditioned by contextual variation.

Implicit within the CAS rubric is also an invitation to mixing qualitative and quantitative analysis. Coppedge (2005) and Lieberman (2005) suggest 'nesting' small-n within large-n global analysis to identify most-similar, most-different, and aberrant across regional domains. However, CAS need not necessarily submit to the hierarchical division of labor implied by beginning with large-n global analysis and then using qualitative methods to examine aberrations (Sil, 2000). To explain the emergence of developmental states in East Asia versus patrimonial, rent-based states in Southeast Asia, Doner et al. (2005) combine a sparse narrative with Boolean-type truth tables to evaluate, pointing to the interaction of rent availability, the ability of the regime to make side payments, and the level of external threat compelling a commitment to infrastructural upgrade as producing different forms of state-society bargains. They are thus able to explain both inter- and intra-regional diversity using the same set of causal propositions.

Another mixed-method approach to understanding regional variation is to forgo dummy variable and interaction terms and instead break up the analysis into different regional models and then compare regional results (Taagepara, 2008: 58). Haggard and Kaufman (2004) do this in their study of differences in public spending patterns among new democracies in Eastern Europe, Latin America, and East Asia. They begin with regression analysis within individual regions and then proceed with comparative historical analysis of particular regional legacies. This bottom-up statistical model building still confronts the obstacles of inadequate degrees of freedom that are seen in multilevel models. Still, similar to the use of seemingly simple descriptive statistics, such an inductive approach allows the researcher to get 'closer' to the data, to examine unexpected patterns of regional diversity or convergence without a priori assumptions about relevant variables typical in large-n crossnational datasets.

Ultimately, while nominal, ordinal, and interval comparative techniques help to make theory development more structured and parsimonious, they are no substitute for the historical narratives in which area studies traditionally excels (Mahoney, 1999). This is because narrative remains the basic method 
by which scholars examine empirically complex and sequential causal chains unfolding in time (Büthe, 2002). Whether in intra-regional bounded generalizations or inter- and cross-regional comparison, this emphasis on induction sets area studies apart from rational choice analytics and global statistical approaches. It maintains the integrity of region-specific knowledge about the multiple layers and multiple iterations of impacts that generate the concrete forms of social changes observed in the world today.

\section{Conclusion}

Regional context is crucial and yet often neglected in both quantitative and qualitative social sciences. Regions should not be treated as simple geographical givens, but as analytic categories capturing specific historical processes resulting in institutional embedding across and between existing states. Attention to the contextual settings in which mechanisms unfold makes area studies a vital component in the practice of social science. Area studies must be more attentive to theoretical grounding of regional schema and explicit about what factors specifically binds regions together in order to increase its relevance to the development of general theory.

CAS increases this leverage by bringing contextual variation into even starker focus, using inter-regional and cross-regional comparison to place regional differences at the foreground. Inevitably, attempts to explain regions with such diverse histories and attributes will begin to sound like 'just-so story', involving contingent conjunctions of factors precipitating unique social outcomes. What CAS offers is the potential to make the mechanisms portable and appreciable in general terms without neglecting historical specificity.

NOTES

1. These debates are also seen in sociology and anthropology. See Robinson (1998) and Guyer (2004), respectively.

2. For a continuation of this argument, see Bunce (2000: 721), King et al. (1994: 35-6) and Levi (1999: 36).

3. See Rokkan (1992, 1999). For further discussion, see Allardt (2007) and Tilly (1984).

4. Efforts to create new datasets based on historical research, as in Acemoglu and Robinson (2001), are laudable but uncommon, as they are extremely labor intensive but still face many of the same challenges of other types of cross-national statistical research, particularly the demographic dilemma of affixing attributes to country units whose borders are not fixed (Abbott, 2001: 40-4, 60).

5. This example comes from Steve Heydemann's ongoing work on the distributional politics in the Middle East. The actual regression coefficients and results are shown in Appendix I.

6. Even James C. Scott, one of the most vocal proponent of local knowledge and critics of rational choice, points out this in his Moral Economy of the Peasant (1977), agents behaved rationally given their circumstances of limited food supply (see interview in Munck and Snyder, 2007b: 360). 
7. A string of edited volumes and a 2001 volume of PS: Political Science and Politics have endeavored to point out the contributions of regional case studies to major social scientific puzzles. Cf. Johnson (1997); Kuhonta et al. (2008); Szanton (2004); and Tessler (1999).

\section{REFERENCES}

Abbott, A. (2001) Time Matters: On Theory and Method. Chicago: University of Chicago Press.

Acemoglu, S.J. and Robinson, J. (2001) 'The Colonial Origins of Comparative Development: An Empirical Investigation', American Economic Review 91(5): 1369-401.

Acharya, A. (2008) 'The Emerging Regional Architecture of World Politics', World Politics 59(4): 629-52.

Achen, C. (2002) 'Toward a New Political Methodology: Microfoundations and ART', Annual Review of Political Science 5: 423-50.

Allardt, E. (2007) 'Reflections on Stein Rokkan's Conceptual Map of Europe', Scandinavian Political Studies 4(4): 257-71.

Basedau, M. and Köllner, P. (2007) 'Area Studies, Comparative Area Studies and the Study of Politics: Context, Substance, and Methodological Challenges', Zeitschrift für Vergleichende Politikwissenschaft 1: 1-20.

Bates, R. (1997) 'Area Studies and the Discipline: A Useful Distinction?', PS: Political Science and Politics 30(2): 166-9.

Bates, R., Grief, A., Levi, M., Rosenthal, J.R. and Weingast, B. (eds) (1998) Analytic Narratives. Princeton, NJ: Princeton University Press.

Bennett, A., Barth, A. and Rutherford, K.R. (2003) 'Do We Preach What We Practice? A Survey of Methods in Political Science Journals and Curricula', PS: Political Science and Society 31(3): 373-8.

Bennett, A. and George, A. (2001) 'Case Studies and Process Tracing in History and Political Science: Similar Strokes for Different Foci’, in C. Elman and M.F. Elman (eds), Bridges and Boundaries: Historians, Political Science, and the Study of International Relations, pp. 137-66. Cambridge, MA: MIT Press.

Beissinger, M. (2007) 'Structure and Example in Modular Political Phenomena: The Diffusion of the Bulldozer/Rose/Orange/Tulip Revolution', Perspectives on Politics 5(2): 259-76.

Beissinger, M. and Young, C. (2002) 'Comparing State Crises Across Two Continents', in M. Beissinger and C. Young (eds), Beyond State Crisis? Postcolonial Africa and PostSoviet Eurasia in Comparative Perspective, pp. 3-18. Baltimore, MD: Johns Hopkins University Press.

Birch, S. (2003) 'Two-Round Electoral Systems and Democracy', Comparative Political Studies 36(3): 319-44.

Blyth, M. (2003) 'Structures Do Not Come with an Instruction Sheet: Interests, Ideas, and Progress in Political Science', Perspectives on Politics 1(4): 695-706.

Bratton, M. (1982) 'Patterns of Development and Underdevelopment: Toward a Comparison', International Studies Quarterly 26(3): 333-72.

Bratton, M. and van de Walle, N. (1994) 'Neopatrimonial Regimes and Political Transitions in Africa', World Politics 46: 453-89.

Brinks, D. and Coppedge, M. (2006) 'Diffusion is No Illusion: Neighbor Emulation in the Third Wave of Democracy', Comparative Political Studies 39(4): 463-89.

Bunce, V. (2000) 'Comparative Democratization: Big and Bounded Generalizations', Comparative Political Studies 33(6/7): 703-34. 
Bunce, V. and Wolchick, S. (2006) 'International Diffusion and Post-Communist Electoral Revolutions', Communist and Post-Communist Studies 39(3): 283-304.

Bunge, M. (1997) 'Mechanism and Explanation', Philosophy of the Social Sciences 27(4): 410-65.

Büthe, T. (2002) 'Taking Temporality Seriously: Modeling History and the Use of Narrative as Evidence', American Political Science Review 96(3): 481-93.

Carpenter, D. (2000) 'Commentary: What is the Marginal Value of Analytic Narratives', Social Science History 24(4): 653-67.

Capoccia, G. and Kelemen, R.D. (2007) 'The Study of Critical Junctures: Theory, Narrative, and Counterfactuals in Historical Institutionalism', World Politics 59: 341-69.

Coppedge, M. (2005) 'Explaining Democratic Deterioration in Venezuela Through Nested Induction', in F. Hagopian and S. Mainwairing (eds) The Third Wave of Democratization in Latin America, pp. 289-318. New York: Cambridge University Press.

DiPrete, T. and Forristal, J.D. (1994) 'Multilevel Models: Methods and Substance', Annual Review of Sociology 20: 331-57.

Doner, R.F., Ritchie, B.K. and Slater, D. (2005) 'Systemic Vulnerability and the Origins of the Developmental States: Northeast and Southeast Asia in Comparative Perspective', International Organization 59(2): 327-61.

Ebbinghaus, B. (2005) 'When Less is More: Selection Problems in Large-N and Small-N Cross National Comparisons', International Sociology 20(2): 133-52.

Ekiert, G. and Hanson, S.E. (2003) 'Time, Space, and Institutional Change in Central and Eastern Europe', in G. Ekiert and S.E. Hanson (eds), Capitalism and Democracy in Central and Eastern Europe: Assessing the Legacy of Communist Rule, pp. 15-48. New York: Cambridge University Press.

Elster, J. (1991) Nuts and Bolts for the Social Sciences. New York: Cambridge University Press.

Emmerson, D.K. (2008) 'Southeast Asia in Political Science: Terms of Enlistment', in E.M. Kuhonta, D. Slater and T. Vu (eds) Southeast Asia in Political Science: Theory, Region, and Qualitative Analysis, pp. 302-59. Stanford, CA: Stanford University Press.

Engelbert, P. (2000) 'Solving the Mystery of the AFRICA Dummy', World Development 28(10): 1821-35.

Falleti, T. and Lynch, J. (2006) 'Context and Causal Heterogeneity in Historical Analysis', Working Paper, Northwestern University Program in ComparativeHistorical Social Science.

Fawcett, L. (2004) 'Exploring RegionalDomains: A Comparative History of Regionalism', International Affairs 80(3): 429-46

Ferrara, F. and E.S. Herron (2005) 'Going It Alone? Strategic Entry under Mixed Electoral Rules', American Journal of Political Science 49(1): 16-31.

Franzese, R.J. (2005) 'Empirical Strategies for Various Manifestations of Multilevel Data', Political Analysis 13(4): 430-46.

Geertz, C. (2000) The Interpretation of Cultures. New York: Basic Books.

Geller, A. and Hill, J. (2007) Data Analysis Using Regression and Multilevel/Hierarchical Models. New York: Cambridge University Press.

George, A. and Bennett, A. (2005) Case Studies and Theory Development in the Social Sciences. Cambridge, MA: MIT Press.

Gerring, J. (2007) Case Study Research: Principles and Practices. New York: Cambridge University Press. 
Gerring, J. (2008) 'The Mechanistic Wave: Thinking Inside the Box', British Journal of Political Science 38(1): 161-79.

Gieryn, T.F. (2000) 'A Space for Place in Sociology', Annual Review of Sociology 26: 463-96.

Goertz, G. with Mahoney, J. (2006) 'Negative Case Selection: The Possibility Principle', in G. Goertz, Social Science Concepts: A User's Guide. Princeton, NJ: Princeton University Press.

Goldstone, J. (1998) 'Initial Conditions, General Laws, Path Dependence, and Explanation in Historical Sociology', American Journal of Sociology 104(3): 829-45.

Guyer, J.I. (2004) 'Anthropology in Area Studies', Annual Review of Anthropology 33: 499-523.

Haggard, S. and Kaufman, R. (2004) 'Revising Social Contracts: Social Spending in Latin America, East Asia, and Socialist Countries, 1980-2000', Revista de Ciencia Politica 24(1): 3-37.

Hanson, S. (2008) 'The Contribution of Area Studies', Qualitative \& Mixed Method Research 6(2): 35-43.

Hechter, M. and Kanazawa, S. (1997) 'Sociological Rational Choice Theory', Annual Review of Sociology 23: 191-294.

Hedström, P. and Swedberg, R. (1996) 'Rational Choice, Empirical Research, and the Sociological Tradition', European Sociological Review 12: 127-46.

Heydemann, S. (2007) 'Social Pacts and the Persistence of Authoritarianism in the Middle East', in O. Schlumberger (ed.), Debating Authoritarianism: Dynamics and Durability in Non-Democratic Regimes. Stanford, CA: Stanford University Press.

Humphrey, M. (2005) 'Natural Resource, Conflict, and Conflict Resolution', Journal of Conflict Resolution 49(4): 508-37.

Huntington, S. (1996) Clash of Civilizations and the Remaking of World Order. New York: Simon \& Schuster.

Johnson, C. (1997) 'Preconception vs. Observation, or the Contribution of Rational Choice Theory and Area Studies to Contemporary Political Science', PS: Political Science and Politics 30(2): 170-4.

Katzenstein, P.J. (2001) 'Area Studies and Regional Studies in the United States', PS: Political Science and Politics 34(4): 789-91.

Katzenstein, P.J. (ed.) (2005) A World of Regions: Asia and Europe in the American Imperium. Ithaca, NY: Cornell University Press.

Katznelson, I. and Weingast, B. (eds) (2005) Preferences and Situations: Points of Intersection Between Historical and Rational Choice Institutionalism. New York: Russell Sage.

King, G. (1996) 'Why Context Shouldn't Matter', Political Geography 15(2): 159-64.

King, G., Keohane, R.O. and Verba, S. (1994) Designing Social Inquiry: Scientific Inference in Qualitative Research. Princeton, NJ: Princeton University Press.

Kittel, B. (2006) 'A Crazy Methodology? On the Limits of Macro-Quantitative Social Science Research', International Sociology 21(5): 647-77.

Kuhonta, E.M., Slater, D. and Vu, T. (eds) (2008) Southeast Asia in Political Science: Theory, Region, and Qualitative Analysis. Stanford, CA: Stanford University Press.

Laitin, D. (1998) Identity in Formation, The Russian-Speaking Populations in the Near Abroad. Ithaca, NY: Cornell University Press.

Levi, M. (1999) 'A Model, a Method, and a Map: Rational Choice in Comparative and Historical Analysis', in M. Lichbach and A. Zuckerman (eds), Comparative Politics: Rationality, Culture, and Structure. New York: Cambridge University Press.

Lewis, B. (2002) 'In the Finger Zone', New York Review of Books 49(9): 2. 
Lewis, M.W. and Wigen, K.E. (1997) The Myth of Continents: A Critique of Metageography. Berkeley, CA: University of California Press.

Li, Q. and Schaub, D. (2004) 'Economic Globalization and Transnational Terrorist Incidents: A Pooled Time Series Cross Sectional Analysis', Journal of Conflict Resolution 48(2): 230-58.

Lieberman, E.S. (2005) 'Nested Analysis as a Mixed-Method Strategy for Comparative Research', American Political Science Review 99(3): 435-52.

Locke, R.M. and Thelen, K. (1995) 'Apples and Oranges Revisited: Contextualized Comparisons and the Study of Comparative Labor Politics', Politics E Society 23(3): 337-67.

Luke, D. (2004) Multilevel Modeling. Thousand Oaks, CA: Sage.

Mahoney, J. (2007) 'Debating the State of Comparative Politics: Views from Qualitative Research', Comparative Political Studies 40(1): 32-8.

Mahoney, J. (1999) 'Nominal, Ordinal, and Narrative Appraisal in Macrocausal Analysis', American Journal of Sociology 104(4): 1154-96.

Mainwaring, S. and Perez-Liñán, A. (2003) 'Level of Development and Democracy: Latin American Exceptionalism, 1945-1996', Comparative Political Studies 36(9): 1031-67.

Mainwaring, S. and Perez-Liñán, A. (2004) 'Studying Latin American Regimes, 1945-99', Paper presented at the American Political Science Association, Chicago.

Mayntz, R. (2004) 'Mechanisms in the Analysis of Social Macro-Phenomena', Philosophy of Social Sciences 34(2): 237-59.

Mirsepassi, A., Basu, A. and Weaver, F. (eds) (2003) Localizing Knowledge in a Globalizing World: Recasting the Area Studies Debate. Syracuse: Syracuse University Press.

Miyoshi, M. and Harootunian, H.D. (eds.) (2002) Learning Places: The Afterlives of Area Studies. Durham, MD: Duke University Press.

Monroe, K.R. (2001) 'Paradigm Shift: From Rational Choice to Perspective', International Political Science Review 22(2): 141-72.

Mozaffar, S., Scarritt, J.R. and Galaich, G. (2003) 'Electoral Institutions, Ethnopolitical Cleavages, and Party Systems in Africa's Emerging Democracies', American Political Science Review 97(3): 379-90.

Mukherjee, B. (2003) 'Political Parties and the Size of Government in Multiparty Legislatures', Comparative Political Studies 36(6): 699-728.

Munck, G. and Snyder, R. (2007a) 'Debating the Direction of Comparative Politics: An Analysis of Leading Journals', Comparative Political Studies 40(1): 5-31.

Munck, G. and Snyder, R. (2007b) Passion, Craft, and Method in Comparative Politics. Baltimore, MD: Johns Hopkins Press.

Nielson, D. (2003) 'Supplying Trade Reform: Political Institutions and Liberalization in Middle-Income Presidential Democracies', American Journal of Political Science 47(3): 470-91.

Olson, M. (1993) 'Dictatorship, Democracy, and Development', American Political Science Review 87(3): 567-76.

O’Loughlin, J., Ward, M.D., Lofdahl, C.L., Cohen, J.S., Brown, D.S., Reilly, D., Gleditsch, K.S. and Shin, M. (1998) 'The Diffusion of Democracy', Annals of the Association of American Geographers 88(4): 545-74.

Peters, G. (2005) Institutional Theory in Political Science: The 'New Institutionalism'. New York: Continuum.

Pierson, P. (2003) 'From Area Studies to Contextualized Comparison', in G. Ekiert and S.E. Hanson (eds), Capitalism and Democracy in Central and Eastern Europe: 
Assessing the Legacy of Communist Rule, pp. 353-76. New York: Cambridge University Press.

Pierson, P. (2004) Politics in Time: History, Institutions, and Social Analysis, Princeton, NJ: Princeton University Press.

Pinto, P.M. and Timmons, J.F. (2005) 'The Political Determinants of Economic Performance', Comparative Political Studies 38(1): 26-50.

Przeworksi, A. and Teune, H. (1970) The Logic of Comparative Social Inquiry. New York: Wiley.

Ragin, C. (2000) Fuzzy-Set Social Science. Chicago: University of Chicago Press.

Ragin, C. (2008) Redesigning Social Inquiry: Fuzzy Sets and Beyond. Chicago: University of Chicago Press.

Roberts, C. (1996) The Logic of Historical Explanation. University Park, FL: Pennsylvania State University Press.

Robinson, W. (1998) 'Beyond Nation-State Paradigms: Globalization, Sociology, and the Challenge of Transnational Studies', Sociological Forum 13(3): 561-94.

Rokkan, S. (1999) State Formation, Nation-Building and Mass Politics in Europe: The Theory of Stein Rokkan (P. Flora, ed.). New York: Oxford University Press.

Rokkan, S. (1992) 'Dimensions of State Formation and Nation-Building: A Possible Paradigm for Research on Variation within Europe', in J. Hall (ed.) The State: Critical Concepts, pp. 25-58. New York: Routledge.

Samuels, D. (2004) 'Presidentialism and Accountability for the Economy in Comparative Perspective', American Political Science Review 98(3): 425-36.

Scott, J. (2009) The Art of Not Being Governed: An Anarchist History of Upland Southeast Asia. New Haven, CT: Yale University Press.

Shapiro, I. (2005) The Flight From Reality in the Human Sciences. Princeton, NJ: Princeton University Press.

Sil, R. (2000) 'The Division of Labor in Social Science Research: Unified Methodology or “Organic Solidarity”?', Polity 32(4): 499-531.

Smith, B. (2004) 'Oil Wealth and Regime Survival in the Developing World', American Journal of Political Science 48(2): 232-46.

Solow, R. (1997) 'How Did Economics Get That Way and What Way Did it Get', Daedalus 126(1): 39-58.

Soltan, K.E. (2004) 'Rational Choice and Theoretical History', in I.L. Morris, J.A. Oppenheimer and K.E. Soltan (eds), Politics from Anarchy to Democracy: Rational Choice in Political Science. Stanford, CA: Stanford University Press.

Steenbergen, M.R. and Jones, B.S. (2002) 'Modeling Multilevel Data Structures', American Journal of Political Science 46(1): 218-37.

Szanton, D. (ed.) (2004) The Politics of Knowledge: Area Studies and the Disciplines. Berkeley, CA: University of California Press.

Taagepera, R. (2008) Making Social Sciences More Scientific: The Need for Predictive Models. New York: Oxford University Press.

Tessler, M. (ed.) (1999) Area Studies and Social Science: Strategies for Understanding Middle East Politics. Bloomington, IN: Indiana University Press.

Thompson, W. (1973) 'The Regional Subsystem: A Conceptual Explication and a Propositional Inventory', International Studies Quarterly 17(1): 89-117.

Timmons, J.F. (2005) 'The Fiscal Contract: States, Taxes, and Public Services', World Politics 57(4): 530-67.

Tilly, C. (1984) Big Structures, Large Processes, Huge Comparisons. New York: Russell Sage. 
Western, B. (1998) 'Causal Heterogeneity in Comparative Research: A Bayesian Hierarchical Modeling Approach', American Journal of Political Science 42(2): 1233-59. Williams, M.E. (2000) 'Theory Driven Comparative Analysis: Dead on the Gurney or Lost in the Shuffle?', Studies in Comparative International Development 35(3): 112-30. Yousef, T. (2004) 'Development, Growth, and Policy Reform in the Middle East and North Africa since 1950', Journal of Economic Perspectives 19(3): 91-116.

ARIEL I. AHRAM is Assistant Professor in the School of International \& Area Studies and the Department of Political Science at the University of Oklahoma. He wishes to thank the anonymous reviewers, as well as Andy Bennett, Dan Hopkins, Gerardo Munck, Dan Slater, the members of the IPSA Committee on Concepts \& Methods and the participants in 2008 ECPR Joint Sessions Workshop for their comments and critiques. Address: School of International \& Area Studies, University of Oklahoma, 729 Elm Avenue, Hester Hall Room 105, Norman, OK 73019, USA. [email: arielahram@ou.edu]

APPENDIX

Dependent Variable: Malnutrition80

\begin{tabular}{lccc}
\hline & Equation 1 & Equation 2 & Equation 3 \\
\hline Constant & 81.581 & 81.439 & 82.591 \\
lnGDP80 & $(4.870)^{* * *}$ & $(4.702)^{* * *}$ & $(4.713)^{* * *}$ \\
& -8.412 & -8.273 & -8.427 \\
MENA & $(.632)^{* * *}$ & $(.612)^{* * *}$ & $(.613)^{* * *}$ \\
Interact & & -10.374 & -24.959 \\
& & $(3.416)^{* * *}$ & $(9.256)^{* * *}$ \\
R sqr & .611 & & 2.036 \\
$\mathrm{~F}$ & $177.221^{* * *}$ & .640 & $(1.202)^{*}$ \\
$\mathrm{~N}$ & 114 & $99.668^{* * *}$ & .649 \\
\hline
\end{tabular}

Standard Error in parenthesis

${ }^{* * *}=p$-value $<.01 ;{ }^{* *}=p$-value $<.05 ;{ }^{*}=p$-value $<.10$ 